\title{
Review of the efficacy and safety of over-the-counter medicine
}

\author{
Gerusa Clazer Halila ${ }^{1,2, *}$, Alexandra Ingrid dos Santos Czepula ${ }^{1}$, Michel Fleith Otuki ${ }^{1,2}$, Cassyano \\ Januário Correr ${ }^{1}$
}

\author{
${ }^{1}$ Pharmacy Department, Federal University of Paraná, Curitiba, PR, Brazil, ${ }^{2}$ Pharmaceutical Sciences Department, State \\ University of Ponta Grossa, Ponta Grossa, PR, Brazil
}

\begin{abstract}
Over-the-counter medicines are available without prescription because of their safety and effectiveness, to treat minor ailments and symptoms. The objective of the study was to analyze the availability and quality of systematic reviews published about nonprescription medicines, identifying the groups for which there are gaps in evidence. We identified published articles through the Cochrane Database of Systematic Review and MEDLINE, from the start of the database until May 2012, using the search terms "nonprescription drugs," "over the counter," and "OTC." We searched for articles that describe systematic reviews addressing the efficacy and safety of drugs dispensed without a prescription, according to the lists published by the Association of the European Self-Medication Industry and in Brazil, in the clinical conditions listed in Groups and Specified Therapeutic Indications. We included 49 articles, 18 articles were of moderate quality and 31 of high quality. Of the studies, $74.5 \%$ demonstrated efficacy in favor of the use of drugs evaluated. Of the 24 studies that evaluated safety, $21 \%$ showed evidence unfavorable to the drug. Overall, the evidence found in the studies included in the overview is favorable to the use of the drugs evaluated. However, there are gaps in evidence for some therapy groups.
\end{abstract}

Uniterms: Nonprescription medicines. Medicines/safety use. Self-medication. Evidence-based health.

\begin{abstract}
Os medicamentos isentos de prescrição são disponíveis sem prescrição médica devido a sua efetividade e segurança, para tratar sintomas e males menores. O objetivo deste trabalho é revisar a disponibilidade e qualidade das revisões sistemáticas publicadas sobre medicamentos isentos de prescrição, identificando os grupos para os quais há lacunas de evidência. Foram identificados artigos publicados através da Cochrane Database of Systematic Review e MEDLINE (via PubMed) desde o início da base até maio de 2012, utilizando os termos "nonprescription drugs," "over the counter," "OTC". Foram procurados artigos que descrevessem revisão sistemática abordando a eficácia e segurança dos medicamentos dispensados sem prescrição, de acordo com as listas publicadas pela Association of the European Self-Medication Industry e no Brasil, nas condições clínicas constantes na lista de Grupos e Indicações Terapêuticas Especificadas. Foram incluídos 49 artigos, 18 artigos eram de qualidade moderada e 31 de alta qualidade. $74,5 \%$ dos estudos demonstraram eficácia favorável ao uso do medicamento avaliado. Dos 24 estudos que avaliaram segurança, $21 \%$ mostraram evidência desfavorável ao uso do medicamento. No geral, a evidência encontrada nos estudos incluídos nesta revisão é favorável ao uso dos medicamentos avaliados. Entretanto, há grupos terapêuticos para os quais há lacunas na evidência.
\end{abstract}

Unitermos: Medicamentos isentos de prescrição. Automedicação. Saúde baseada em evidências.

\section{INTRODUCTION}

According to the World Health Organization (WHO), over-the-counter (OTC) medicines are drugs

*Correspondence: G. C. Halila. Federal University of Paraná. Av. Pref. Lothário Meissner, 632 - Jardim Botânico - 80210-170 - Curitiba - PR, Brasil. E-mail: gerusach@hotmail.com approved by health authorities to treat minor ailments and symptoms. They are available without prescription because of their safety and effectiveness, if used in accordance with the guidelines available on the package inserts and on labels (ABIMIP, 2012).

In Brazil, this class of drugs is regulated by Board Resolution (RDC) of the National Agency for Sanitary Surveillance (ANVISA) Number 138 of May 29, 
2003, which provides for the sale category of products (ANVISA, 2003). According to ANVISA, OTC drugs can be registered as medicines that meet the conditions of the list of Groups and Specified Therapeutic Indications (GITE).

The Association of the European Self-Medication Industry (AESGP) has lists of nonprescription drugs marketed in 36 countries. These lists group the drugs according to their chemical, pharmacological, and therapeutic characteristics, according to the Anatomical Therapeutic Chemical (ATC) Classification System established by WHO. In this case, the symbol "OTC" means that at least one dosage or form of the drug has the legal status of nonprescription medication in some of the countries considered (ABIMIP, 2012).

Although OTC medicines are considered relatively safe drugs to be dispensed without a prescription, some studies, like the one conducted by Smith et al. (2012), call into question their efficacy and safety because of the lack of good quality trials. In this sense, evidence-based health (EBH) assumes that the behavior of professionals in clinical practice should be based on the best scientific evidence available at the time (Guaudard, 2008). Thus, EBH integrates clinical expertise with the ability to analyze and apply rational scientific information (Lopes, 2000; Manchikanti et al., 2009).

With respect to studies of treatment, systematic reviews (SR) are considered currently to provide the highest level of evidence in relation to any clinical question (El Dib, 2007), as the SR and meta-analyses are useful for monitoring important innovations in healthcare. A systematic review of systematic reviews (overview) is a survey designed primarily to summarize data from several reviews, focusing on the effects of clinical interventions on a health condition; this is carried out in order to analyze the quality of systematic reviews and inform readers how failures may influence the results (Higgins, Green, 2011).

The aim of this study was to analyze the availability and quality of systematic reviews published about nonprescription medicines, identifying the groups for which there are gaps in evidence.

\section{METHODS}

\section{Data sources}

We performed the overview of systematic reviews, following a pre-established protocol, according to the PRISMA model (Preferred Reporting Items for Systematic Reviews and Meta-Analyses) (Moher et al., 2009). A systematic search was performed on the Cochrane
Database of Systematic Reviews (CDSR) and MEDLINE (via PubMed) over the period from the beginning of the database until May 2012. To seek systematic reviews in PubMed the following strategy was used for the search: (systematic review* [tiab] OR meta-analysis [pt] OR meta-analysis[tiab] OR systematic literature review [tiab] OR "Cochrane Database Syst Rev" [Journal] OR (search*[tiab] AND (medline or embase OR peer-review* OR literature OR "evidence-based" OR pubmed OR IPA or "international pharmaceutical abstracts"))) NOT (letter [pt] OR newspaper article [pt] OR comment [pt]) AND hasabstract AND ("Nonprescription Drugs" [Mesh] OR "Nonprescription Drugs" [tiab] OR OTC*[tiab] OR "over the counter" [tiab]). To format the Cochrane Library the following strategy was used: \#1 (systematic review OR meta-analysis OR "evidence-based"):ti,ab,kw; \#2 ("Nonprescription Drugs" OR OTC OR "over the counter"):ti,ab,kw; \#1 AND \#2.

\section{Study selection}

After obtaining the articles, all the steps of the process were performed by two independent reviewers (GCH and AISC), and discrepancies were resolved by consensus. In the absence of agreement, the assistance of a third reviewer (CJC) was requested. The process for selecting the studies followed the PRISMA model (Moher et al., 2009): (a) all articles were analyzed based on their titles and abstracts (screening); (b) the articles deemed relevant were then fully analyzed by two reviewers, noting the inclusion and exclusion criteria (eligibility); and (c) articles that met all the criteria were included in the data collection (inclusion). Articles that generated questions during screening were included and passed through the eligibility stage for examination in full. In addition, we performed a manual search of references in all articles read in full. A search was not performed for unpublished articles or articles in conference proceedings. To be included, articles had to fulfill the following criteria: there was a systematic review, with or without meta-analysis; they addressed the efficacy and safety of nonprescription medicines considered according to lists released by AESGP and OTC drugs in Brazil; the clinical conditions were listed in the GITE list.

The exclusion criteria were: (a) items whose full text was not available through the databases or after contact with the author; (b) items that did not describe or were overviews of systematic reviews; (c) systematic reviews that included only prescription drugs; (d) articles that evaluated the use of medicinal herbs, vitamins, and supplements; (e) items that were defined as systematic 
reviews, but whose full text did not comply with items 4, 7 and 9 of the PRISMA checklist (provide an explicit statement of questions being addressed with reference to participants, interventions, comparisons, outcomes, and study design; describe all sources of information in the search and date last searched; indicate the selection process of the study) (Moher et al., 2009).

\section{Data extraction}

Data were extracted in duplicate and disagreements were resolved by consensus between the reviewers. At the stage of full reading a critical evaluation of the studies was made in order to verify the methodological quality of the reviews and possible sources of bias present in each review through the Assessment of Multiple Systematic Reviews (AMSTAR) instrument developed by Shea et al. (2009).

The AMSTAR total score was obtained by adding one point for each "yes" answer, while any other answer did not receive a point. The score ranged from 0 (zero), as the worst quality, to 11 (eleven) as the best quality. In addition, studies were categorized as proposed by the work of Mikton and Butchart (2009) in which a score from 0 to 4 indicated a review of low quality, from 5 to 8 indicated moderate quality, and from 9 to 11 indicated high quality. To collect data on efficacy and safety we used a second standard instrument developed by the authors.

\section{RESULTS AND DISCUSSION}

By searching the databases, 228 articles of potential relevance were found, but only 23 were included. The supplementary manual search selected 26 articles, so a total of 49 were included in the overview (see flowchart as shown in Figure 1). Of these, six articles were published in the 90s and others after 2000. The collected data from the included studies are shown in Table I.

Three articles were outdated and were therefore replaced by updating the manual search (Smith et al., 2012). Among the articles included by supplementary manual search, two were withdrawn from The Cochrane Library for lack of update (De Sutter et al., 2009; Taverner, Latte, 2009), as recommended by the Cochrane Collaboration (Higgins, Green, 2011).

In order to widen the scope of this overview, we included an extensive list of such OTC drugs marketed in 36 countries and in Brazil. Then, some of the medicines included are not OTC drugs in Brazil, for example, diclofenac, sumatriptan, and ranitidine are OTC medicines in some countries in Europe.

Considering the conditions encountered in clinical

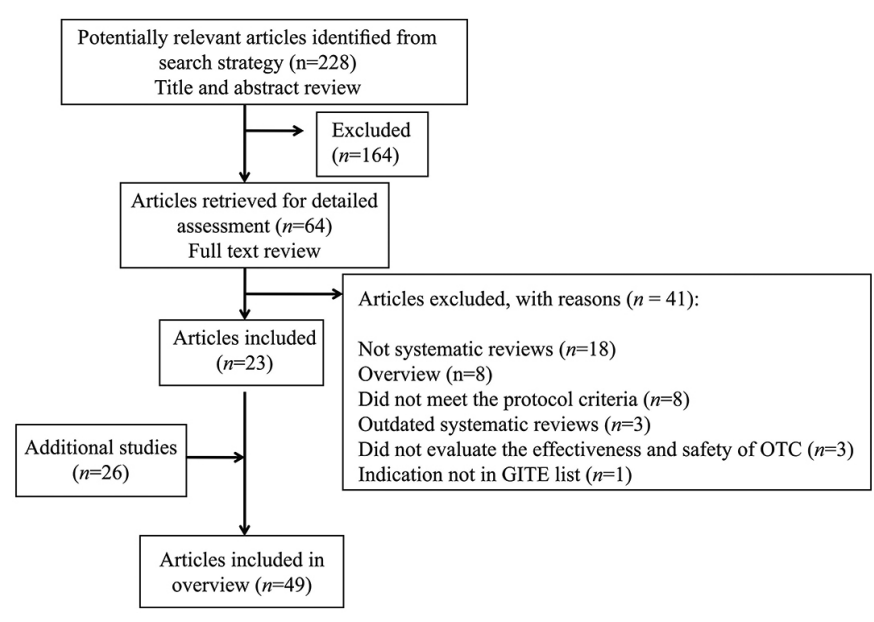

FIGURE 1 - Flowchart for the selection of systematic reviews included in the overview.

studies, it can be seen that most of the articles evaluated patients with acute or chronic pain $(35.4 \%)$ or specifically migraine $(14.6 \%)$. Studies to evaluate the efficacy and safety of medicines used to combat pain are extremely important, since self-medication in this context is a reality. Other clinical conditions assessed in this overview were quitting smoking (10.4\%), cough (8.3\%), symptoms of common cold (8.3\%), fever and/or pain (8.3\%), constipation (8.3\%), fungal infections (4.2\%), and dyspepsia (2.1\%). Only one study (Jenkins, Costello, Hodge, 2004) assessed the safety of the drug against various clinical conditions.

Compared with the GITE list, various therapeutic groups and clinical indications have not been evaluated by systematic reviews, using the proposed strategy. There are, therefore, gaps for groups such as antidiarrheal, antispasmodic, antiparasitic, and antiseptic medicines in general.

Of the 24 studies that evaluated safety, five (21\%) showed evidence unfavorable to the drug, due to significant side effects presented (Edwards et al., 1999; Jenkins; Costello, Hodge, 2004; De Sutter et al., 2009; Derry, Moore, 2012; Derry C. et al., 2012). Data of security should be considered when dispensing medicines, especially in regard to OTC drugs, to encourage rational use of these medications.

With regard to studies on the efficacy of OTC medicines, 35 articles (74.5\%) showed evidence favorable for the use of the intervention in at least one of the groups of patient studied. Three studies (6.4\%) did not show evidence favorable to the drug's efficacy. In one of these, the use of antihistamines was not proven effective in the treatment of common cold symptoms and showed more side effects compared to placebo (De Sutter et al., 2009). Another 
TABLE I - Main characteristics of systematic reviews on OTC drugs

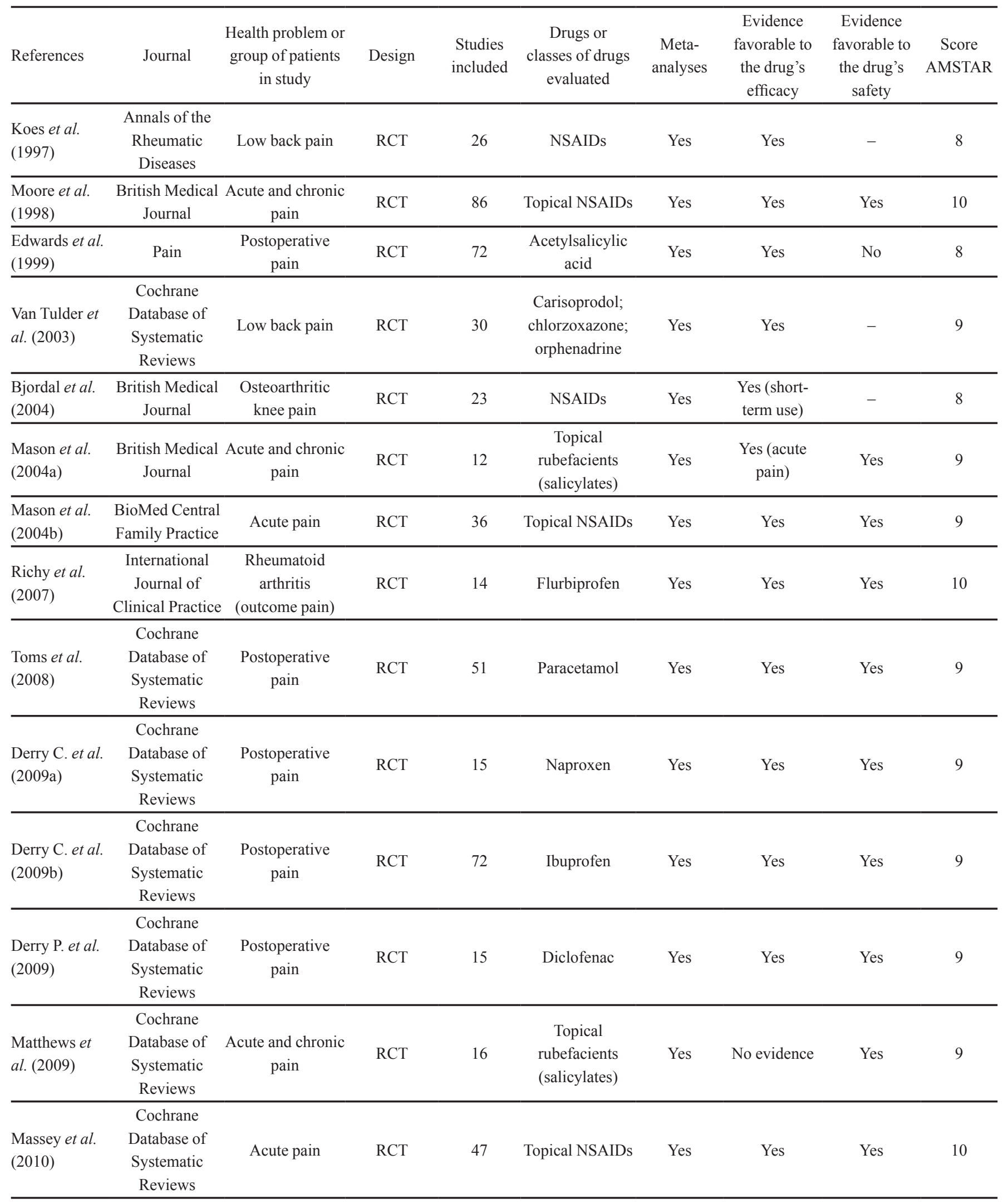


TABLE I - Main characteristics of systematic reviews on OTC drugs (cont.)

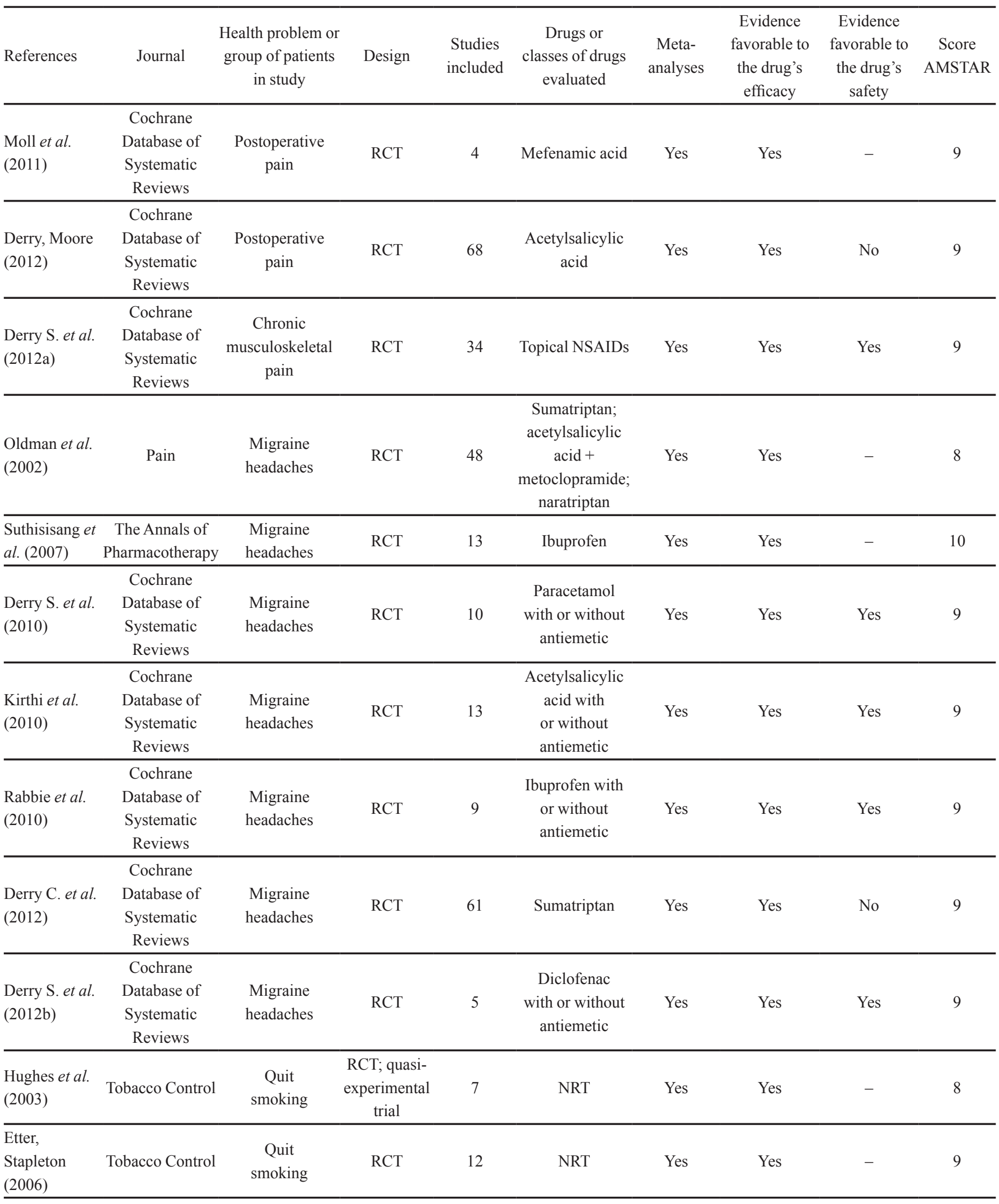


TABLE I - Main characteristics of systematic reviews on OTC drugs (cont.)

\begin{tabular}{|c|c|c|c|c|c|c|c|c|c|}
\hline References & Journal & $\begin{array}{l}\text { Health problem or } \\
\text { group of patients } \\
\text { in study }\end{array}$ & Design & $\begin{array}{l}\text { Studies } \\
\text { included }\end{array}$ & $\begin{array}{c}\text { Drugs or } \\
\text { classes of drugs } \\
\text { evaluated }\end{array}$ & $\begin{array}{c}\text { Meta- } \\
\text { analyses }\end{array}$ & $\begin{array}{l}\text { Evidence } \\
\text { favorable to } \\
\text { the drug's } \\
\text { efficacy }\end{array}$ & $\begin{array}{l}\text { Evidence } \\
\text { favorable to } \\
\text { the drug's } \\
\text { safety }\end{array}$ & $\begin{array}{c}\text { Score } \\
\text { AMSTAR }\end{array}$ \\
\hline Walsh (2008) & $\begin{array}{c}\text { Drug and } \\
\text { Alcohol Review }\end{array}$ & $\begin{array}{c}\text { Quit } \\
\text { smoking }\end{array}$ & $\begin{array}{c}\text { RCT; } \\
\text { observational } \\
\text { studies }\end{array}$ & 12 & NRT & No & No & - & 7 \\
\hline $\begin{array}{l}\text { Stead et al. } \\
\text { (2012) }\end{array}$ & $\begin{array}{c}\text { Cochrane } \\
\text { Database of } \\
\text { Systematic } \\
\text { Reviews }\end{array}$ & $\begin{array}{c}\text { Quit } \\
\text { smoking }\end{array}$ & $\begin{array}{l}\text { RCT; quasi- } \\
\text { experimental } \\
\text { trial }\end{array}$ & 150 & NRT & Yes & Yes & - & 10 \\
\hline $\begin{array}{l}\text { Schroeder, } \\
\text { Fahey (2002b) }\end{array}$ & $\begin{array}{l}\text { Archives of } \\
\text { Disease in } \\
\text { Childhood }\end{array}$ & $\begin{array}{l}\text { Cough in } \\
\text { children }\end{array}$ & $\mathrm{RCT}$ & 6 & $\begin{array}{l}\text { Antitussives; } \\
\text { expectorants; } \\
\text { mucolytics; } \\
\text { antihistamine- } \\
\text { decongestant } \\
\text { combinations; } \\
\text { other drug } \\
\text { combinations }\end{array}$ & No & No & - & 8 \\
\hline $\begin{array}{l}\text { Smith et al. } \\
\text { (2012) }\end{array}$ & $\begin{array}{c}\text { Cochrane } \\
\text { Database of } \\
\text { Systematic } \\
\text { Reviews }\end{array}$ & $\begin{array}{l}\text { Cough in adults } \\
\text { and children }\end{array}$ & $\mathrm{RCT}$ & 26 & $\begin{array}{l}\text { Antitussives; } \\
\text { expectorants; } \\
\text { mucolytics; } \\
\text { antihistamine- } \\
\text { decongestant } \\
\text { combinations; } \\
\text { other drug } \\
\text { combinations }\end{array}$ & No & Inconclusive & - & 9 \\
\hline $\begin{array}{l}\text { Kollar et al. } \\
(2007)\end{array}$ & $\begin{array}{c}\text { Clinical } \\
\text { Therapeutics }\end{array}$ & $\begin{array}{l}\text { Alleviating nasal } \\
\text { symptoms of } \\
\text { common cold }\end{array}$ & $\mathrm{RCT}$ & 8 & Phenylephrine & Yes & Yes & - & 6 \\
\hline $\begin{array}{l}\text { De Sutter, et } \\
\text { al. (2009) }\end{array}$ & $\begin{array}{c}\text { Cochrane } \\
\text { Database of } \\
\text { Systematic } \\
\text { Reviews }\end{array}$ & $\begin{array}{l}\text { Alleviating nasal } \\
\text { symptoms of } \\
\text { common cold }\end{array}$ & $\mathrm{RCT}$ & 32 & Antihistamines & Yes & No & No & 9 \\
\hline
\end{tabular}


TABLE I - Main characteristics of systematic reviews on OTC drugs (cont.)

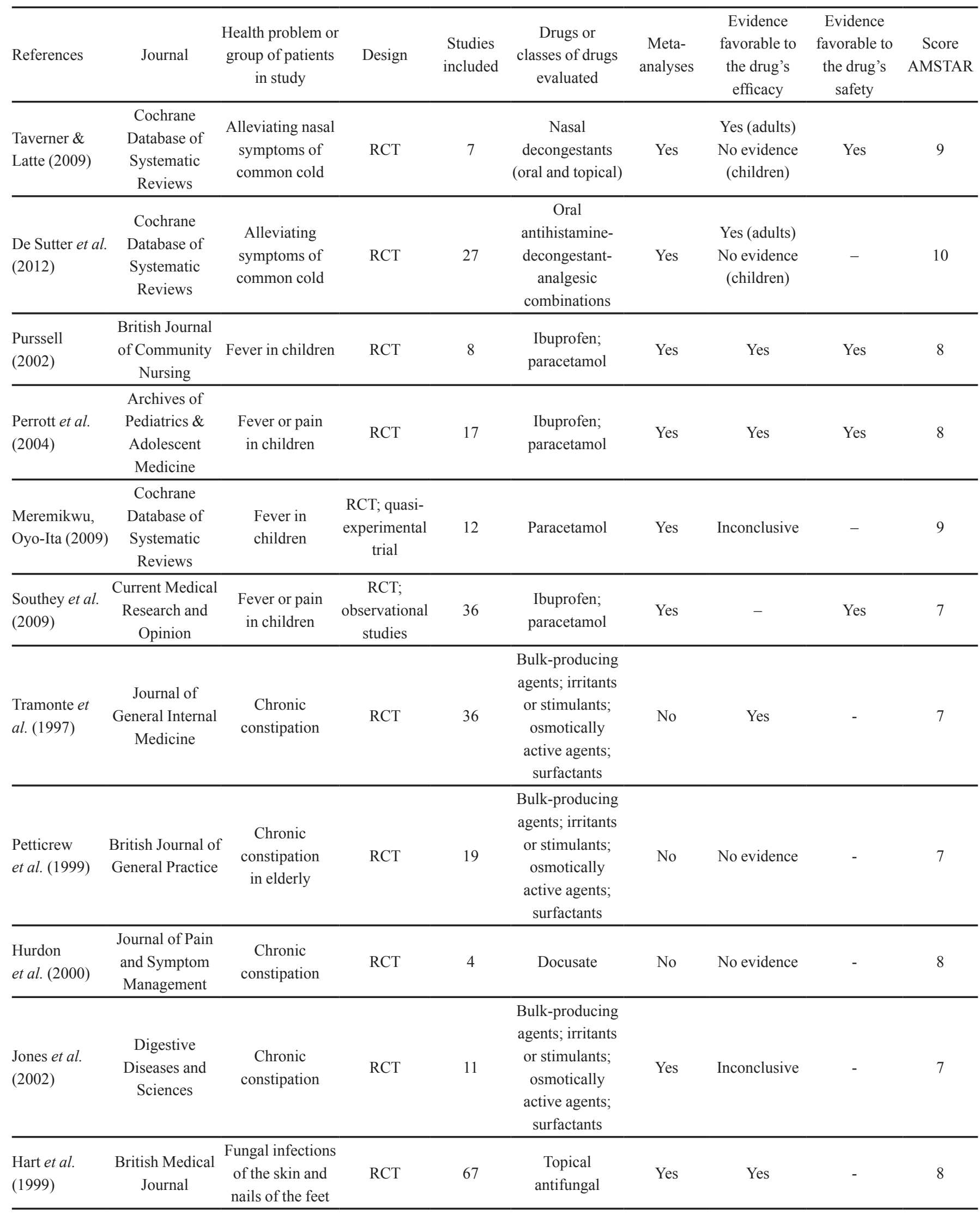


TABLE I - Main characteristics of systematic reviews on OTC drugs (cont.)

\begin{tabular}{|c|c|c|c|c|c|c|c|c|c|}
\hline References & Journal & $\begin{array}{l}\text { Health problem or } \\
\text { group of patients } \\
\text { in study }\end{array}$ & Design & $\begin{array}{l}\text { Studies } \\
\text { included }\end{array}$ & $\begin{array}{c}\text { Drugs or } \\
\text { classes of drugs } \\
\text { evaluated }\end{array}$ & $\begin{array}{c}\text { Meta- } \\
\text { analyses }\end{array}$ & $\begin{array}{l}\text { Evidence } \\
\text { favorable to } \\
\text { the drug's } \\
\text { efficacy }\end{array}$ & $\begin{array}{l}\text { Evidence } \\
\text { favorable to } \\
\text { the drug's } \\
\text { safety }\end{array}$ & $\begin{array}{c}\text { Score } \\
\text { AMSTAR }\end{array}$ \\
\hline $\begin{array}{l}\text { Crawford, } \\
\text { Hollis (2007) }\end{array}$ & $\begin{array}{c}\text { Cochrane } \\
\text { Database of } \\
\text { Systematic } \\
\text { Reviews }\end{array}$ & $\begin{array}{l}\text { Fungal infections } \\
\text { of the skin and } \\
\text { nails of the feet }\end{array}$ & RCT & 67 & $\begin{array}{c}\text { Topical } \\
\text { antifungal }\end{array}$ & Yes & Yes & - & 10 \\
\hline $\begin{array}{l}\text { Tran et al. } \\
(2007)\end{array}$ & $\begin{array}{c}\text { Alimentary } \\
\text { Pharmacology \& } \\
\text { Therapeutics }\end{array}$ & Dyspepsia & RCT & 14 & $\begin{array}{l}\text { Histamine-2 } \\
\text { receptor } \\
\text { antagonists; } \\
\text { alginates; } \\
\text { antacids }\end{array}$ & Yes & Yes & - & 9 \\
\hline
\end{tabular}

Abbreviations used: NSAIDs, Non-steroidal anti-inflammatory drugs; RCT, randomized controlled trial; NRT, nicotine replacement therapy.

study evaluating the efficacy of nicotine replacement therapy (NRT), without prescription, concluded that the superiority of OTC NRT over unaided smoking cessation had not been demonstrated convincingly (Walsh, 2008). Likewise, the use of medications for coughs were reported in children and the results do not demonstrate greater efficacy than a placebo, noting the small number of trials found (Schroeder, Fahey, 2002b). The other three studies related to treatment of coughs showed no good evidence in favor of the use of these medicines (Schroeder, Fahey, 2002a, Chang, Cheng, Chang, 2012; Smith et al., 2012). Moreover, some systematic reviews were inconclusive or showed no evidence for the use of the drug, suggesting more studies.

Concerning the methodological quality of systematic reviews, according to the evaluation by the AMSTAR instrument, 18 reviews were of moderate quality (namely, AMSTAR score of 5-8), 31 were of high quality (9-11), and no reviews received a score of 0 to 4 , which indicates a review of low quality. These data suggest that the methodological quality of reviews showed that the majority of the published studies are of good quality. Moreover, we noticed that all the systematic reviews conducted by the Cochrane Collaboration were of high quality.

Among the items examined those that mostly did not receive the answer "yes" were item numbers 10 and 11 of the AMSTAR instrument. Item 10 verifies that the likelihood of publication bias was assessed, which is the tendency for studies with positive results to be more often published than studies with negative results (Zhou, Obuchowski, McClish, 2002). The possibility of the occurrence of this type of bias was not reported in 42 articles $(86 \%)$. Item 11 evaluates whether a conflict of interest was included in the study; namely, potential sources of support should be clearly recognized in both the systematic review and in the studies included (Shea et al., 2009). Although some studies have reported sources of support, there was no explicit statement of this in $32(65 \%)$ of the reviews. Similar results were found in the literature (Santaguida et al., 2013; Remschmidt, Wichmann, Harder, 2014), demonstrating the need to improve the description of potential conflicts of interest and publication bias.

Relating the quality of studies to clinical conditions, we note that all studies on constipation showed moderate methodological quality. The same occurred with three studies (of four) evaluating fever and/or pain and three studies (of five) on quitting smoking. In this case, in addition to the items described above, some reviews failed in describing other items, such as showing a list of excluded studies, describing if the studies undertook duplicate study selection and extraction, and rarely undertaking meta-analyses.

Regarding the design of the studies found in the systematic review, in just one review (Hughes et al., 2011) did the design not include a randomized clinical trial (RCT). According to the author, prospective controlled trials are the best way to assess effectiveness by determining the effect of therapy on the actual conditions of use. Another four studies, in addition to RCTs, employed non-randomized studies (Hughes et al., 2003), observational studies (Southey, Soares-Weiser, Kleijnen, 2009), quasi-randomized trials (Meremikwu, Oyo-Ita, 2009; Stead et al., 2012), and cohort studies (Walsh, 
2008). The Cochrane Collaboration focuses primarily on systematic reviews of randomized clinical trials because they are more likely to provide unbiased information than other study designs (Higgins, Green, 2011).

The sale of medicines without the need to present a prescription suggests that they are safe and effective. Thus, systematic reviews, which correspond to the highest level of evidence to evaluate the efficacy and safety of nonprescription medicines, are essential contributions to their rational use. The present study examined 49 systematic reviews published up to May 2012, which show no evidence of efficacy or safety for at least three of the nine clinical conditions assessed. This leads us to think that the use of such medicines in certain clinical conditions is questionable.

Our overview also presents some limitations. In our search strategy, we chose a query with greater specificity, instead of a higher sensitivity, for considering the large number of OTC drugs marketed. Moreover, many of the authors of systematic reviews on OTC medications do not use general descriptors such as "nonprescription drugs" or "OTC," which makes the location of these in databases difficult. In order to minimize the possible omission of studies due to this fact, we conducted a manual search of work in the bibliographies of all the studies read in full. Finally, we constrained the inclusion of systematic reviews only to those health conditions considered treatable with OTC medications. This was necessary, considering the existence of several reviews involving OTC drugs for conditions which require prior medical diagnosis, which would be outside the scope of our work. In order to avoid biases related to this aspect, we included an extensive list of such OTC drugs marketed in 36 countries and in Brazil.

\section{CONCLUSION}

The methodological quality of systematic reviews of nonprescription medicines, according to studies included, is moderate to high. Thus, the quality of the available evidence in these is good enough for their use in clinical practice. The evidence found in the studies included in the overview is favorable to the use of most of the drugs evaluated, like topical antifungal, analgesics, and antiinflammatory drugs. However, some systematic reviews were inconclusive or showed no evidence for the use of the drug, suggesting more studies, as in the case of nicotine replacement therapy without prescription, medications for coughs, and chronic constipation. Then, there are therapy groups for which there are gaps in evidence, necessitating the need for studies in this area.

\section{REFERENCES}

ASSOCIAÇÃO BRASILEIRA DA INDÚSTRIA DE MEDICAMENTOS ISENTOS DE PRESCRIÇÃO. ABIMIP. Available from: $<$ http://www.abimip. org.br/site/ index.php>. Acessed on: 2 Feb. 2012.

AGÊNCIA NACIONAL DE VIGILÂNCIA SANITÁRIA. ANVISA. Resolução RDC nº. 138, de 29 de maio de 2003. Dispõe sobre o enquadramento na categoria de venda de medicamentos. Diário Oficial da União, Brasília, 2 jun. 2003.

BJORDAL, J.M.; LJUNGGREN, A.E.; KLOVNING, A.; SLORDAL, L. Non-steroidal anti-inflammatory drugs, including cyclo-oxygenase-2 inhibitors, in osteoarthritic knee pain: meta-analysis of randomised placebo controlled trials. $B M J$, v.329, n.7478, p.1317, 2004.

CHANG, C.C.; CHENG, A.C.; CHANG, A.B. Over-thecounter (OTC) medications to reduce cough as an adjunct to antibiotics for acute pneumonia in children and adults. Cochrane Database Syst Rev., CD006088, 2014.

CRAWFORD, F.; HOLLIS, S. Topical treatments for fungal infections of the skin and nails of the foot. Cochrane Database Syst. Rev., n.3, CD001434, 2007.

DE SUTTER, A.I., LEMIENGRE, M.; CAMPBELL, H. WITHDRAWN: Antihistamines for the common cold. Cochrane Database Syst. Rev., n.4, CD001267, 2009.

DE SUTTER, A.I.; VAN DRIEL, M.L.; KUMAR, A.A.; LESSLAR, O.; SKRT, A. Oral antihistamine-decongestantanalgesic combinations for the common cold. Cochrane Database Syst. Rev., v.2, CD004976, 2012.

DERRY, C.; DERRY, S.; MOORE, R.A.; MCQUAY, H.J. Single dose oral naproxen and naproxen sodium for acute postoperative pain in adults. Cochrane Database Syst. Rev., n.1, CD004234, 2009a.

DERRY, C.; DERRY, S.; MOORE, R.A.; MCQUAY, H.J. Single dose oral ibuprofen for acute postoperative pain in adults. Cochrane Database Syst. Rev., n.3, CD001548, 2009 b.

DERRY, C.J.; DERRY, S.; MOORE, R.A. Sumatriptan (oral routes of administration) for acute migraine attacks in adults. Cochrane Database Syst. Rev., v.2, CD008615, 2012. 
DERRY, p.; DERRY, S.; MOORE, R.A.; MCQUAY, H.J. Single dose oral diclofenac for acute postoperative pain in adults. Cochrane Database Syst. Rev., n.2, CD004768, 2009.

DERRY, S.; MOORE, R.A. Single dose oral aspirin for acute postoperative pain in adults. Cochrane Database Syst. Rev., n.4, CD002067, 2012.

DERRY, S.; MOORE, R.A.; MCQUAY, H.J. Paracetamol (acetaminophen) with or without an antiemetic for acute migraine headaches in adults. Cochrane Database Syst. Rev., n.11, CD008040, 2010. Update in: Cochrane Database Syst. Rev., v.4, CD008040, 2013.

DERRY, S.; MOORE, R.A.; RABBIE, R. Topical NSAIDs for chronic musculoskeletal pain in adults. Cochrane Database Syst.Rev., n.9, CD007400, 2012a.

DERRY, S.; RABBIE, R.; MOORE, R. A. Diclofenac with or without an antiemetic for acute migraine headaches in adults. Cochrane Database Syst Rev., v.2, CD008783, 2012b. Update in: Cochrane Database Syst Rev., v.4, CD0087, 2013.

EDWARDS, J.E.; OLDMAN, A.D.; SMITH, L.A.; CARROLL, D.; WIFFEN, p.J.; MCQUAY, H.J.; MOORE, A. Oral aspirin in postoperative pain: a quantitative systematic review. Pain, v.81, n.3, p.289-297, 1999.

EL DIB, R.P. How to practice evidence-based medicine. J. Vasc. Bras., v.6, n.1, p.1-4, 2007.

ETTER, J.F.; STAPLETON, J.A. Nicotine replacement therapy for long-term smoking cessation: a meta-analysis. Tob Control., v.15, n.4, p.280-285, 2006.

GUAUDARD, A.M. Medicina Baseada em Evidência, uma reflexão. Com Ciências Saúde, v.19, p.297-398, 2008.

HART, R.; BELL-SYER, S.E.; CRAWFORD, F.; TORGERSON, D.J.; YOUNG, p.; RUSSELL, I. Systematic review of topical treatments for fungal infections of the skin and nails of the feet. BMJ, v.319, n.7202, p.79-82, 1999.

HIGGINS, J.P. T.; GREEN, S. (Eds). Cochrane handbook for systematic reviews of interventions version 5.1.0 [updated March 2011]. The Cochrane Collaboration, 2011. Available from: <www.cochrane-handbook.org > . Acessed on: 2 Feb. 2012.
HUGHES, J.R.; SHIFFMAN, S.; CALLAS, p.; ZHANG, J. A meta-analysis of the efficacy of over-the-counter nicotine replacement. Tob Control., v.12, n.1, p.21-27, 2003.

HUGHES, J.R.; PETERS, E.N. ; NAUD, S. Effectiveness of over-the-counter nicotine replacement therapy: a qualitative review of nonrandomized trials. Nicotine Tob Res., v.13, n.7, p.512-522, 2011. Erratum in: Nicotine Tob Res., v.14, n.12, p.1499, 2012.

HURDON, v.; VIOLA, R.; SCHRODER, C. How useful is docusate in patients at risk for constipation? A systematic review of the evidence in the chronically ill. J. Pain Symptom Manage., v.19, n.2, p.130-136, 2000.

JENKINS, C.; COSTELLO, J.; HODGE, L. Systematic review of prevalence of aspirin induced asthma and its implications for clinical practice. BMJ, v.328, n.7437, p.434, 2004.

JONES, M.P. ; TALLEY, n.J.; NUYTS, G.; DUBOIS, D. Lack of objective evidence of efficacy of laxatives in chronic constipation. Dig. Dis. Sci., v .47, n.10, p.222-2230, 2002.

KIRTHI, v.; DERRY, S.; MOORE, R.A.; MCQUAY, H.J. Aspirin with or without an antiemetic for acute migraine headaches in adults. Cochrane Database Syst. Rev., n.4, CD008041, 2010. Update in: Cochrane Database Syst. Rev., v.4, CD008041, 2013.

KOES, B.W.; SCHOLTEN, R.J.; MENS, J.M.; BOUTER, L.M. Efficacy of non-steroidal anti-inflammatory drugs for low back pain: a systematic review of randomised clinical trials. Ann. Rheum. Dis., v.56, p.214-223, 1997.

KOLLAR, C.; SCHNEIDER, H.; WAKSMAN, J.; KRUSINSKA, E. Meta-analysis of the efficacy of a single dose of phenylephrine $10 \mathrm{mg}$ compared with placebo in adults with acute nasal congestion due to the common cold. Clin. Ther., v.29, n.6, p.1057-1070, 2007.

LOPES, A.A. Medicina baseada em evidências: a arte de aplicar o conhecimento científico na prática clínica. Rev. Assoc. Med. Bras. v. 46 n. 3, p.285-288, 2000.

MANCHIKANTI, L.; BENYAMIN, R.M.; HELM, S.; HIRSCH, J.A. Evidence-based medicine, systematic reviews, and guidelines in interventional pain management: part 3: systematic reviews and meta-analyses of randomized trials. Pain Physician, v.12, n.1, p.35-72, 2009. 
MASON, L.; MOORE, R.A.; EDWARDS, J.E.; MCQUAY, H.J.; DERRY, S.; WIFFEN, p.J. Systematic review of efficacy of topical rubefacients containing salicylates for the treatment of acute and chronic pain. $B M J$, v.328, n.7448, p.995, 2004a.

MASON, L.; MOORE, R.A.; EDWARDS, J. E.; DERRY, S.; MCQUAY, H. J. Topical NSAIDs for acute pain: a metaanalysis. BMC Farm. Pract., v.5, p.10, 2004 b.

MASSEY, T.; DERRY, S.; MOORE, R.; MCQUAY, H. J. Topical NSAIDs for acute pain in adults. Cochrane Database Syst. Rev., n.6, CD007402, 2010.

MATTHEWS, p.; DERRY, S.; MOORE, R.A.; MCQUAY, H.J. Topical rubefacients for acute and chronic pain in adults. Cochrane Database Syst. Rev., n.3, CD007403, 2009.

MEREMIKWU, M.M.; OYO-ITA, A. Paracetamol versus placebo or physical methods for treating fever in children. Cochrane Database of Syst. Rev., n.9, CD003676, 2009.

MIKTON, C.; BUTCHART, A. Child maltreatment prevention: a systematic review of reviews. Bull. World Health Organ., v.87, p.353-361, 2009.

MOHER, D.; LIBERATI, A.; TETZLAFF, J.; ALTMAN, D.G.; The PRISMA Group. Preferred reporting items for systematic reviews and meta-analyses: the PRISMA statement. BMJ, v.339, p.b2535, 2009.

MOLL, R.; DERRY, S.; MOORE, R.A.; MCQUAY, H. J. Single dose oral mefenamic acid for acute postoperative pain in adults. Cochrane Database Syst.Rev., n.3, CD007553, 2011.

MOORE, R.A.; TRAMÈR, M.R.; CARROLL, D.; WIFFEN, p.J.; MCQUAY, H.J. Quantitive systematic review of topically applied non-steroidal anti-inflammatory drugs. $B M J$, v.316, n.7128, p.333-338, 1998. Erratum in: $B M J$, v.316, n.7137, p.1059, 1998.

OLDMAN, A.D.; SMITH, L.A.; MCQUAY, H.J, MOORE, R.A. Pharmacological treatments for acute migraine: quantitative systematic review. Pain, v.97, n.3, p.247-257, 2002.

PERROTT, D.A.; PIIRA, T.; GOODENOUGH, B.; CHAMPION, G.D. Efficacy and safety of acetaminophen vs ibuprofen for treating children's pain or fever: a metaanalysis. Arch.Pediatr. Adolesc. Med., v.158, n.6, p.521526, 2004.
PETTICREW, M.; WATT, I.; BRAND, M. What's the 'best buy' for treatment of constipation? Results of a systematic review of the efficacy and comparative efficacy of laxatives in the elderly. Br. J.Gen. Pract., v.49, n.442, p.387-393, 1999.

PURSSELL, E. Treating fever in children: paracetamol or ibuprofen?. Br. J. Community Nurs., v.7, n.6, p.316-320, 2002.

RABBIE, R.; DERRY, S.; MOORE, R.A.; MCQUAY, H.J. Ibuprofen with or without an antiemetic for acute migraine headaches in adults. Cochrane Database Syst. Rev., n.10, CD008039, 2010. Update in: Cochrane Database Syst. Rev., v.4, CD008039, 2013.

REMSCHMIDT, C.; WICHMANN, O.; HARDER, T. Methodological quality of systematic reviews on influenza vaccination. Vaccine, v.32, n.15, p.1678-1684, 2014.

RICHY, F.; RABENDA, v.; MAWET, A.; REGINSTER, J.Y. Flurbiprofen in the symptomatic management of rheumatoid arthritis: a valuable alternative. Int.J. Clin. Pract., v.61, n.8, p.1396-1406, 2007.

SANTAGUIDA. P. L.; KESHAVARZ, H.; CARLESSO, L.C.; LOMOTAN, M.; GROSS, A.; MACDERMID, J.C.; WALTON, D.M.; ICON WORKING GROUP. A description of the methodology used in an overview of reviews to evaluate evidence on the treatment, harms, diagnosis/classification, prognosis and outcomes used in the management of neck pain. Open Orthop., v.7, p.461472, 2013.

SCHROEDER, K.; FAHEY, T. Systematic review of randomised controlled trials of over the counter cough medicines for acute cough in adults. BMJ, v.324, n.7333, p.329-331, 2002a.

SCHROEDER, K.; FAHEY, T. Should we advise parents to administer over the counter cough medicines for acute cough? Systematic review of randomised controlled trials. Arch. Dis. Child., v.86, n.3, p.170-175, 2002b.

SHEA, B.J.; HAMEL, C.; WELLS, G.A.; BOUTER, L.M.; KRISTJANSSON, E.; GRIMSHAW, J.; HENRY, D.A.; BOERS, M. AMSTAR is a reliable and valid measurement tool to assess the methodological quality of systematic reviews. J. Clin. Epidemiol., v.62, p.1013-1020, 2009. 
SMITH, S.M.; SCHROEDER, K.; FAHEY, T. Over-the-counter (OTC) medications for acute cough in children and adults in ambulatory settings. Cochrane Database Syst. Rev., n.8, CD001831, 2012.

SOUTHEY, E.R.; SOARES-WEISER, K.; KLEIJNEN, J. Systematic review and meta-analysis of the clinical safety and tolerability of ibuprofen compared with paracetamol in paediatric pain and fever. Curr. Med. Res. Opin., v.25, n.9, p.2207-2222, 2009.

STEAD, L.F.; PERERA, R.; BULLEN, C.; MANT, D.; HARTMANN-BOYCE, J.; CAHILL, K.; LANCASTER, T. Nicotine replacement therapy for smoking cessation. Cochrane Database Syst. Rev., v.11, CD000146, 2012.

SUTHISISANG, C.; POOLSUP, n.; KITTIKULSUTH, W.; PUDCHAKAN, p.; WIWATPANICH, p.Efficacy of lowdose ibuprofen in acute migraine treatment: systematic review and meta-analysis. Ann. Pharmacother., v.41, n.11, p.1782-1791, 2007.

TAVERNER, D.; LATTE, G.J. WITHDRAWN: Nasal decongestants for the common cold. Cochrane Database of Syst. Rev., n.2, CD001953, 2009.

TOMS, L.; MCQUAY, H. J.; DERRY, S.; MOORE, R. A. Single dose oral paracetamol (acetaminophen) for postoperative pain in adults. Cochrane Database Syst. Rev., n.4, CD004602, 2008.
TRAMONTE, S.M.; BRAND, M.B.; MULROW, C.D.; AMATO, M.G.; O'KEEFE, M. E.; RAMIREZ, G. The treatment of chronic constipation in adults. A systematic review. J. Gen. Intern. Med., v.12, n.1, p.15-24, 1997.

TRAN, T.; LOWRY, A.M.; EL-SERAG, H.B. Meta-analysis: the efficacy of over-the-counter gastro-oesophageal reflux disease therapies. Aliment. Pharmacol. Ther., v.25, n.2, p.143-153, 2007.

VAN TULDER, M.W.; TOURAY, T.; FURLAN, A.D.; SOLWAY, S.; BOUTER, L. M. Muscle relaxants for nonspecific low back pain. Cochrane Database Syst. Rev., n.2, CD004252, 2003.

WALSH, R.A. Over-the-counter nicotine replacement therapy: a methodological review of the evidence supporting its effectiveness. Drug Alcohol Rev., v.27, n.5, p.529-547, 2008.

ZHOU, X.; OBUCHOWSKI, n.; MCCLISH, D. Issues in meta-analysis for diagnostic tests. In: ZHOU, X.; OBUCHOWSKI, n.; MCCLISH, D., (Eds.). Statistical methods in diagnostic medicine. New York: Wiley \& Sons, Inc, 2002. p. 222-240.

Received for publication on $02^{\text {nd }}$ May 2014 Accepted for publication on $12^{\text {th }}$ November 2014 